\title{
Papers
}

\section{Cross sectional study of conventional cervical smear, monolayer cytology, and human papillomavirus DNA testing for cervical cancer screening}

Joël Coste, Béatrix Cochand-Priollet, Patricia de Cremoux, Catherine Le Galès, Isabelle Cartier, Vincent Molinié, Sylvain Labbé, Marie-Cécile Vacher-Lavenu, Philippe Vielh, for the French Society of Clinical Cytology Study Group

\begin{abstract}
Objectives To compare the sensitivity, specificity, and interobserver reliability of conventional cervical smear tests, monolayer cytology, and human papillomavirus testing for screening for cervical cancer.

Design Cross sectional study in which the three techniques were performed simultaneously with a reference standard (colposcopy and histology).

Setting Public university and private practices in France, with complete independence from the suppliers.

Participants 828 women referred for colposcopy because of previously detected cytological abnormalities and 1757 women attending for routine smears.

Main outcome measures Clinical readings and optimised interpretation (two blind readings followed, if necessary, by consensus). Sensitivity, specificity, and weighted $\kappa$ computed for various thresholds of abnormalities.

Results Conventional cervical smear tests were more often satisfactory $(91 \% v 87 \%)$ according to the Bethesda system, more reliable (weighted $\kappa 0.70 v 0.57$ ), and had consistently better sensitivity and specificity than monolayer cytology. These findings applied to clinical readings and optimised interpretations, low and high grade lesions, and populations with low and high incidence of abnormalities. Human papillomavirus testing associated with monolayer cytology, whether systematic or for atypical cells of undetermined significance, performed no better than conventional smear tests.
\end{abstract}

Conclusions Monolayer cytology is less reliable and more likely to give false positive and false negative results than conventional cervical smear tests for screening for cervical cancer.

\section{Introduction}

Liquid based "monolayer" cytology, possibly combined with human papillomavirus testing, is replacing conventional smear tests for cervical cancer screening in several countries (including the United States and Switzerland). However, there is substantial controversy about whether the new and costly technologies perform better than conventional cervical smear tests. ${ }^{12}$ We previously compared the cost of monolayer cytology (ThinPrep, CYTYC; MA, USA) and human papillomavirus testing (Hybrid Capture II test, Digene; Gaithersburg, MD, USA) with conventional smear tests. ${ }^{3}$ Here we assess the sensitivity and specificity of the three methods. We also examined the value of human papillomavirus testing in women with atypical squamous cells/glandular cells of undetermined significance (ASCUS/AGUS) and the interobserver reproducibility of the interpretation of conventional smears and monolayer cytology.

\section{Methods}

Full details of the study protocol have been published previously. ${ }^{4}$ To avoid spectrum (case mix) bias ${ }^{5}$ we considered two groups of consecutive women who were either referred for colposcopy because abnormalities had been detected on previous smears or were attending for routine smears at a French public university $(n=2)$ and private practices $(n=2)$. All procedures were carried out by skilled gynaecologists and experienced cytopathologists. Each woman underwent a standard conventional smear test. The remaining material was then used to prepare the monolayer slide and for human papillomavirus testing. To avoid work up bias, all women were evaluated by all three methods (conventional cervical smear tests, monolayer cytology, human papillomavirus testing) and by the reference method (colposcopy ${ }^{6}$ followed by biopsy if abnormalities were detected). To avoid review and context biases ${ }^{7}$ cytopathologists read the slides blind to the clinical context in addition to routine reading, separately and independently for the three methods. In cases of disagreement slides were read again to reach a consensus conclusion, given if necessary by an independent expert (optimised diagnosis). In a random sample of the women $(30 \%)$ we assessed interobserver reproducibility of cytological diagnosis with readings blind to context.

Smear abnormalities were classified into five ordered categories (negative, ASCUS/AGUS, low
Département de Biostatistique, Hôpital Cochin, Assistance

Publique-Hôpitaux

de Paris, Faculté de Médecine

Cochin-Port Royal, Université Paris V,

Paris, France

Joël Coste

professor of medical statistics

Service d'Anatomie et Cytologie Pathologiques,

Hopital

Lariboisière,

Publique-Hôpit

de Paris, Paris,

France

Béatrix

Cochand-Priollet assistant professor of pathology

Laboratoire de Physiopathologie, Département de Biologie des Tumeurs, Institut Curie, Paris, France

Patricia de

Cremoux

assistant professor of pharmacology

Centre for Health

Economics and

Administration

Research

(CREGAS),

INSERM

U537-CNRS

UPRESA 8052, Le

Kremlin-Bicêtre,

France

Catherine Le Galès senior economist

Laboratoire Cartier,

Paris, France

Isabelle Cartier

pathologist

continued over

bmj.com 2003;326:733 
Service d'Anatomie et Cytologie

Pathologiques,

Hôpital Foch,

Suresnes, France

Vincent Molinié

pathologist

Centre d'Anatomie

Pathologique,

Besançon, France

Sylvain Labbé

pathologist

Service d'Anatomie

et Cytologie

Pathologiques,

Hôpital Cochin

Marie-Cécile

Vacher-Lavenu

professor of pathology

Service de

Cytométrie clinique,

France

Philippe Vielh

pathologist

Correspondence to:

coste@cochin.

univ-paris5.fr
Cytopathologie et

Institut Curie, Paris

grade (LSIL) or high grade (HSIL) squamous intraepithelial lesions, invasive cancer) and the reference standard into four ordered categories (normal colposcopy or negative biopsy result, cervical intraepithelial neoplasia (grades I, II, and III), invasive carcinoma ${ }^{8}$ ). We used optimised histological diagnoses for the reference standard. We carried out human papillomavirus testing using the cell suspension that remained after monolayer preparation ${ }^{9}$ using low risk (types 6/11/ 42/43/44) and high risk (types 16/18/31/33/35/39/ $45 / 51 / 52 / 56 / 58 / 59 / 68$ ) human papillomavirus probes.

\section{Analysis}

We compared the sensitivity, specificity, and proportions of unsatisfactory (according to the Bethesda sys$\mathrm{tem}^{8}$ ) or limited slides using the two tailed MacNemar $\chi^{2}$ test. The interobserver reproducibility of the readings was assessed with weighted $\kappa$ statistics. ${ }^{10}$

To assess potential "sampling bias" due to the split sample technique (monolayer being sampled after conventional cervical smears) we repeated statistical analyses in the subsample of women in whom the residual material after monolayer cytology was sufficient for human papillomavirus testing. The results were similar to those for the whole group and are not shown.

\section{Results}

Between 1 September 1999 and 30 May 2000, 2585 women underwent investigation (table 1). Results of human papillomavirus testing were available from the

Table 1 Characteristics of studied samples by population. Values are numbers (percentage) unless otherwise stated

\begin{tabular}{|c|c|c|}
\hline & $\begin{array}{l}\text { Women referred for } \\
\text { colposcopy }(n=828)\end{array}$ & $\begin{array}{l}\text { Women attending for } \\
\text { routine smear } \\
(n=1757)\end{array}$ \\
\hline Mean (SD) age (years) & $37.8(11.6)$ & $33.3(11.1)$ \\
\hline French & $605(73)$ & $1579(90)$ \\
\hline \multicolumn{3}{|l|}{ Educational: } \\
\hline No schooling or primary only & $74(9)$ & $66(4)$ \\
\hline Secondary & $472(57)$ & $927(53)$ \\
\hline Higher & $276(34)$ & $757(43)$ \\
\hline Current smokers & $337(41)$ & $542(31)$ \\
\hline Mean (SD) age at first intercourse (years) & $18.5(2.7)$ & $18.4(2.1)$ \\
\hline Previous clinical pelvic inflammatory disease & $13(2)$ & $12(1)$ \\
\hline Previous documented Chlamydia trachomatis infection & $16(2)$ & $13(1)$ \\
\hline Mean (SD) No of pregnancies & $2.0(2)$ & $1.2(1.6)$ \\
\hline Menopausal & $119(14)$ & $144(8)$ \\
\hline First smear & 0 & $220(13)$ \\
\hline Previous abnormal smears & $828(100)$ & $68(5)$ \\
\hline \multicolumn{3}{|l|}{ Contraception: } \\
\hline Combined oral contraceptive & $368(44)$ & $913(52)$ \\
\hline Intrauterine device & $90(11)$ & $176(10)$ \\
\hline Condoms & $49(6)$ & $53(3)$ \\
\hline HIV positive & $10(1)$ & $5(0)$ \\
\hline \multicolumn{3}{|l|}{ Centre: } \\
\hline Hôpital Jean Verdier (public, Paris suburbs) & $35(4)$ & $70(4)$ \\
\hline Hôpital Louis Mourier (public, Paris suburbs) & $238(29)$ & $54(3)$ \\
\hline Laboratoire Cartier (private, Paris) & $520(63)$ & $559(32)$ \\
\hline Centre d'Anatomie pathologique (private, Besançon) & $35(4)$ & $1074(61)$ \\
\hline \multicolumn{3}{|l|}{ Results of colposcopy *: } \\
\hline Normal & $131(16)$ & $1405(80)$ \\
\hline Acetowhite epithelium & $389(47)$ & $146(8)$ \\
\hline Iodine negative epithelium & $665(80)$ & $322(18)$ \\
\hline
\end{tabular}

${ }^{\star}$ Acetowhite and iodine negative epithelium are not mutually exclusive so the total exceeds $100 \%$.
1785 women for whom there was enough residual material. The proportion of satisfactory slides was higher with conventional smear testing (91\%) than with monolayer testing $(87 \%)$, though the reasons for unsatisfactory or limited smears differed (table 2). Compared with conventional smear tests monolayer testing consistently showed more abnormalities (especially ASCUS/AGUS) (tables 3 and 4).

Conventional smear tests consistently had superior or equivalent sensitivity, specificity, and likelihood ratios than monolayer tests for the detection cervical intraepithelial neoplasia grade I or higher (table 5) and lesions $\geq$ grade II or higher (table 6 ). The sensitivity of systematic human papillomavirus DNA testing (high risk) was no higher than that of conventional smear testing and its specificity was much lower for both grades. For human papillomavirus testing only for ASCUS/AGUS, the sensitivity of the paired monolayer/human papillomavirus testing method was not significantly superior to cervical smear testing.

Interobserver agreement was good for conventional smears (weighted $\kappa 0.69,95 \%$ confidence interval 0.64 to 0.74 ) but only moderate for monolayers $(0.57,0.52$ to 0.63 ) (table 7). The ASCUS/AGUS diagnosis with monolayer testing was especially unreliable.

\section{Discussion}

Our results support the superiority of conventional cervical smear testing, whether considered clinical readings or optimised interpretations, low or high grade lesions, or populations with a low or a high incidence of abnormalities. Human papillomavirus testing, systematic or for a diagnosis of ASCUS/AGUS testing, carried out with monolayer cytology was no better than conventional cervical smear testing. The greater reliability of the interpretation of conventional smears rather than monolayer smears is consistent with their better diagnostic or screening performance. Our findings disagree with those of most previous studies.

We ensured that we obtained the reference standard of colposcopy/histology for all women in the study, unlike previous studies that compared monolayer testing with conventional smear testing and that considered concordant positive and concordant negative tests as true positives and true negatives with discrepancies resolved by consensus review. ${ }^{11-20}$ In these studies the proportion of verified cases varied between $0.1 \%$ and $30 \%$, and the work up bias was substantial, artificially inflating sensitivity and mathematically favouring the test with the higher rate of false positives: the monolayer technique (or human papillomavirus testing). Two other studies either did not find any difference between the methods ${ }^{21}$ or performed post hoc subgroup analyses. ${ }^{22}$

\section{Limitations of study}

In this study the cervical smear was prepared before the monolayer. However, a sampling bias favouring the conventional smear is unlikely as there were very few monolayer slides with only a few cells and the results were similar in the subgroup of women in whom human papillomavirus testing was still possible. ${ }^{23}$ The rates of unsatisfactory and limited slides were low, which may be due to our selection of skilled physicians. The cytopathologists were also selected according to their interest in 
reading smears: all had extensive experience in conventional smears and cervical biopsies, but their experience with monolayer cytology was initially limited. However, this bias was neutralised by the optimised interpretations in which the best assessment was obtained.

\section{Implications}

This study has implications for regulation of medical devices, clinical practice, and future research on screening for cervical cancer. Monolayer testing, which seems less reliable and less valid and is more expensive, ${ }^{3}$ should not replace conventional smear tests for cervical cancer screening. Human papillomavirus testing as complementary to conventional smear testing should be further evaluated in clinical research. ${ }^{24}$ Our results emphasise the need to improve the "hard evidence" in studies of new technologies for cervical screening by using adequate methodological standards.

Members of the French Society of Clinical Cytology Study Group: S Arkwright, A Biaggi, C Besançon-Roux, L Carbillon, I Cartier, B Cochand-Priollet (clinical coordinator), J Coste (methodological coordinator), J Darondel, P Dauvergne, P de Cremoux, A Dosda, E Foucher, I Gouget, D Grondard, B Karkouche, S Labbé, C Le Galès, I Le Guen, V Lepoutre, N Lestrat, H Magdelenat, A Malvy-Nickles, E Merea, V Molinié, A Odier, A Petitjean, S Peschard, P Piquet, L Pommaret, X Sastre-Garau, V Saha, N Seince, C Sigal-Hummel, M C Vacher-Lavenu, P Vielh, M Ziol.

Contributors: JC, M-CV-L, VM, BC-P, CLG, and PV initiated the study and developed the study protocol. JC and $\mathrm{BCP}$ coordinated the study. BCP, PdeC, IC, VM, M-CV-L, SL, and PV participated in coordinating the study, data collection, and edit-
Table 2 Specimen adequacy and causes of inadequacy and limitation by method (clinical reading) ${ }^{\star}$

\begin{tabular}{lcc} 
& $\begin{array}{c}\text { Conventional cervical smear } \\
(\mathbf{n}=\mathbf{2 5 8 2})^{*}\end{array}$ & Monolayer (n=2580)† \\
\hline Satisfactory for evaluation & $2343(91 \%)$ & $2241(87 \%) \ddagger$ \\
\hline $\begin{array}{l}\text { Satisfactory for evaluation but limited } \\
\text { by§: }\end{array}$ & 236 & 328 \\
\hline Cytolysis & 6 & 19 \\
\hline Obscuring blood & 36 & 25 \\
\hline Obscuring inflammation & 79 & 44 \\
\hline Endocervical component absent & 75 & 235 \\
\hline Scant squamous epithelial cells & 3 & 4 \\
\hline Air drying artefacts & 32 & 0 \\
\hline Staining problem & 5 & 1 \\
\hline Unsatisfactory for evaluation: & 3 & 11 \\
\hline Cytolysis & 0 & 0 \\
\hline Obscuring blood & 0 & 5 \\
\hline Obscuring inflammation & 0 & 1 \\
\hline Endocervical component absent & 0 & 0 \\
\hline Scant squamous epithelial cells & 1 & 5 \\
\hline Air drying artefacts & 2 & 0 \\
\hline Staining problem & 0 & 0
\end{tabular}

\section{*Data missing data for three.}

†Data missing for five.

$\neq \mathrm{P}<0.0001$ for difference between groups (MacNemar $\chi^{2}$ test).

$\S$ Causes of limited evaluation were not mutually exclusive.

ing. JC calculated the sample size and designed and performed the analysis. JC prepared the manuscript with input from all other authors, revised the manuscript for resubmission, and is the guarantor.

Funding: Direction Générale de la Santé and Programme Hospitalier de Recherche Clinique, French Ministry of Health

Table 3 Interpretation of conventional cervical smear tests* or monolayer testing versus $\dagger$ reference standard (colposcopy and biopsy) by population

\begin{tabular}{|c|c|c|c|c|c|c|c|c|c|c|}
\hline \multirow[b]{2}{*}{$\begin{array}{l}\text { Reference standard } \\
\text { results }\end{array}$} & \multicolumn{5}{|c|}{ Women referred for colposcopy } & \multicolumn{5}{|c|}{ Women attending for routine smears } \\
\hline & Normal & $\begin{array}{l}\text { ASCUS/ } \\
\text { AGUS }\end{array}$ & LSIL & HSIL & $\begin{array}{l}\text { Invasive } \\
\text { cancer }\end{array}$ & Normal & $\begin{array}{l}\text { ASCUS/ } \\
\text { AGUS }\end{array}$ & LSIL & HSIL & $\begin{array}{l}\text { Invasive } \\
\text { cancer }\end{array}$ \\
\hline \multicolumn{11}{|c|}{ Conventional cervical smear (optimised interpretation) } \\
\hline $\begin{array}{l}\text { Normal } \\
\text { colposcopy/ } \\
\text { negative biopsy }\end{array}$ & 231 & 26 & 25 & 7 & 0 & 1510 & 77 & 54 & 11 & 0 \\
\hline CIN grade I & 30 & 21 & 157 & 37 & 0 & 22 & 11 & 22 & 6 & 0 \\
\hline CIN grades II-III & 14 & 8 & 19 & 230 & 7 & 4 & 5 & 6 & 20 & 0 \\
\hline Invasive cancer & 0 & 2 & 0 & 6 & 7 & 1 & 1 & 0 & 3 & 1 \\
\hline \multicolumn{11}{|c|}{ Monolayer (optimised interpretation) } \\
\hline $\begin{array}{l}\text { Normal } \\
\text { colposcopy/ } \\
\text { negative biopsy }\end{array}$ & 220 & 24 & 35 & 9 & 0 & 1493 & 73 & 73 & 15 & 0 \\
\hline CIN grade I & 37 & 23 & 158 & 25 & 0 & 22 & 9 & 18 & 12 & 0 \\
\hline CIN grades II-III & 19 & 10 & 32 & 212 & 4 & 5 & 3 & 5 & 22 & 0 \\
\hline Invasive cancer & 0 & 3 & 0 & 9 & 3 & 0 & 0 & 1 & 4 & 0 \\
\hline \multicolumn{11}{|c|}{ Conventional cervical smear (clinical reading) } \\
\hline $\begin{array}{l}\text { Normal } \\
\text { colposcopy/ } \\
\text { negative biopsy }\end{array}$ & 175 & 31 & 63 & 21 & 0 & 1550 & 59 & 37 & 6 & 1 \\
\hline CIN grade I & 18 & 20 & 173 & 33 & 0 & 23 & 8 & 24 & 6 & 0 \\
\hline CIN grades II-III & 9 & 6 & 35 & 218 & 10 & 5 & 4 & 9 & 18 & 0 \\
\hline Invasive cancer & 1 & 0 & 0 & 3 & 11 & 1 & 1 & 0 & 2 & 1 \\
\hline \multicolumn{11}{|c|}{ Monolayer (clinical reading) } \\
\hline $\begin{array}{l}\text { Normal } \\
\text { colposcopy/ } \\
\text { negative biopsy }\end{array}$ & 166 & 34 & 59 & 27 & 0 & 1503 & 85 & 51 & 9 & 0 \\
\hline CIN grade I & 29 & 29 & 157 & 30 & 0 & 26 & 9 & 15 & 11 & 0 \\
\hline$\overline{\text { CIN grades II-III }}$ & 11 & 12 & 37 & 211 & 7 & 8 & 4 & 7 & 17 & 0 \\
\hline Invasive cancer & 1 & 1 & 0 & 7 & 6 & 1 & 0 & 0 & 4 & 0 \\
\hline
\end{tabular}

ASCUS/AGUS=atypical squamous cells/glandular cells of undetermined significance.

LSIL=low grade squamous intraepithelial lesions.

HSIL=high grade squamous intraepithelial lesions.

$\mathrm{CIN}=$ cervical intraepithelial neoplasia.

${ }^{*}$ Data missing for three to five conventional slides.

†Data missing for 11 monolayer slides 
(AOM 98010); Association pour la Recherche sur le Cancer (9099). The guarantor accepts full responsibility for the conduct of the study, had access to the data, and controlled the decision to publish.

Competing interests: None declared.

Ethical approval: The approval of the ethics committee (Hôpital Cochin, Paris) for the study was obtained in July 1998.

1 Nanda K, McCrory DC, Myers ER, Bastian LA, Hasselblad V, Hickey JD et al. Accuracy of the Papanicolaou test in screening for and follow-up of cervical cytologic abnormalities: a systematic review. Ann Intern Med 2000;132:810-9

2 Hartmann KE, Nanda K, Hall S, Myers E. Technologic advances for evaluation of cervical cytology: is newer better? Obstet Gynecol Sur 2001;56:765-74.
3 Merea E, Le Galès C, Cochand-Priollet B, Cartier I, de Cremoux P, Vacher-Lavenu MC, et al. Cost of screening for cancerous and precancerous lesions of the cervix. Diagn Cytopathol 2002;27:251-7.

4 Cochand-Priollet B, Le Galès C, de Cremoux P, Molinié V, Sastre-Garau $\mathrm{X}$, Vacher-Lavenu MC, et al. Cost-effectiveness of monolayers and human papillomavirus testing compared to that of conventional Papanicolaou smears for cervical cancer screening: protocol of the study of the French Society of Clinical Cytology. Diagn Cytopathol 2001:24:412-20.

5 Reid MC, Lachs MS, Feinstein AR. Use of methodological standards in diagnostic test research. Getting better but still not good. JAMA 1995;274:645-51.

6 Stafl A, Wilbanks GD. An international terminology of colposcopy: report of the Nomenclature Committee of the International Federation of Cervical Pathology and Colposcopy. Obstet Gynecol 1991;77:313-4.

7 Egglin TK, Feinstein AR. Context bias. A problem in diagnostic radiology. JAMA 1996;276:1752-5.

Table 4 Interpretation of conventional cervical smear testing* versus monolayer tests $†$ by population

Result with monolayer test

\begin{tabular}{|c|c|c|c|c|c|c|c|c|c|c|}
\hline & & & & & & \multirow{2}{*}{\multicolumn{5}{|c|}{ Women attending for routine smears }} \\
\hline \multirow{2}{*}{$\begin{array}{l}\text { Result with } \\
\text { conventional cervical } \\
\text { smear test }\end{array}$} & \multicolumn{5}{|c|}{ Women referred for colposcopy } & & & & & \\
\hline & Normal & $\begin{array}{c}\text { ASCUS/ } \\
\text { AGUS }\end{array}$ & LSIL & HSIL & $\begin{array}{c}\text { Invasive } \\
\text { cancer }\end{array}$ & Normal & $\begin{array}{l}\text { ASCUS/ } \\
\text { AGUS }\end{array}$ & LSIL & HSIL & $\begin{array}{c}\text { Invasive } \\
\text { cancer }\end{array}$ \\
\hline \multicolumn{11}{|c|}{ Optimised interpretation } \\
\hline Normal & 229 & 19 & 17 & 7 & 0 & 1445 & 51 & 32 & 7 & 0 \\
\hline ASCUS/AGUS & 19 & 17 & 16 & 3 & 0 & 48 & 21 & 15 & 9 & 0 \\
\hline LSIL & 15 & 17 & 160 & 9 & 0 & 20 & 11 & 45 & 6 & 0 \\
\hline HSIL & 12 & 7 & 32 & 227 & 2 & 4 & 2 & 5 & 29 & 0 \\
\hline Invasive cancer & 0 & 0 & 0 & 9 & 5 & 0 & 0 & 0 & 1 & 0 \\
\hline \multicolumn{11}{|l|}{ Clinical reading } \\
\hline Normal & 147 & 17 & 26 & 9 & 0 & 1480 & 66 & 23 & 3 & 0 \\
\hline ASCUS/AGUS & 24 & 14 & 18 & 1 & 0 & 39 & 20 & 9 & 4 & 0 \\
\hline LSIL & 30 & 34 & 181 & 26 & 0 & 15 & 11 & 36 & 8 & 0 \\
\hline HSIL & 6 & 9 & 28 & 230 & 2 & 1 & 1 & 5 & 25 & 0 \\
\hline Invasive cancer & 0 & 1 & 0 & 9 & 11 & 1 & 0 & 0 & 1 & 0 \\
\hline
\end{tabular}

ASCUS/AGUS=atypical squamous cells/glandular cells of undetermined significance. LSIL=low grade squamous intraepithelial lesions. HSIL=high grade squamous intraepithelial lesions.

${ }^{*}$ Data missing for three to five conventional slides.

tData missing for 11 monolayer slides.

Table 5 Sensitivity, specificity, and likelihood ratios of conventional cervical smear testing, monolayer, and human papillomavirus (HPV) DNA testing for detection of cervical intraepithelial neoplasia grade I and above

Colposcopy

\begin{tabular}{|c|c|c|c|c|c|c|}
\hline \multirow[b]{2}{*}{ Abnormality threshold } & \multicolumn{3}{|c|}{ Colposcopy } & \multicolumn{3}{|c|}{ Screening } \\
\hline & Sensitivity(95\% CI) & Specificity(95\% CI) & $\begin{array}{l}\text { Likelihood ratio+/ } \\
\text { likelihood ratio- }\end{array}$ & Sensitivity(95\% CI) & Specificity $(95 \%$ CI) & $\begin{array}{l}\text { Likelihood ratio+/ } \\
\text { likelihood ratio- }\end{array}$ \\
\hline \multicolumn{7}{|l|}{$\geq$ ASCUS/AGUS* } \\
\hline Cervical smear (clinical reading) & 95 (93 to 97$)$ & 60 (55 to 66$)$ & $2.39 / 0.09$ & 72 (63 to 80$)$ & 94 (93 to 95$)$ & $11.49 / 0.30$ \\
\hline Monolayer (clinical reading) & 92 (90 to 95$)$ & 58 (52 to 64$)$ & $2.19 / 0.13$ & 66 (56 to 75$)$ & 91 (90 to 93$)$ & $7.47 / 0.38$ \\
\hline $\begin{array}{l}\text { Cervical smear (optimised } \\
\text { interpretation) }\end{array}$ & 92 (90 to 94$)$ & 80 (75 to 85$)$ & $4.58 / 0.10$ & 74 (66 to 83 ) & 91 (90 to 93 ) & $8.64 / 0.28$ \\
\hline Monolayer (optimised interpretation) & 90 (87 to 92 ) & 76 (71 to 81$)$ & $3.79 / 0.14$ & 73 (65 to 82$)$ & 90 (89 to 92$)$ & $7.53 / 0.30$ \\
\hline \multicolumn{7}{|c|}{$\geq$ Low grade squamous intraepithelial lesions $\dagger$} \\
\hline Cervical smear (clinical reading) & 90 (87 to 92$)$ & 71 (66 to 76$)$ & $3.11 / 0.14$ & 59 (49 to 68$)$ & 97 (97 to 98$)$ & $22.10 / 0.42$ \\
\hline Monolayer (clinical reading) & 85 (82 to 88$)$ & 70 (65 to 75$)$ & $2.81 / 0.22$ & 53 (43 to 63 ) & 96 (95 to 97$)$ & $14.54 / 0.49$ \\
\hline $\begin{array}{l}\text { Cervical smear (optimised } \\
\text { interpretation) }\end{array}$ & 86 (83 to 89 ) & 89 (85 to 93$)$ & $7.77 / 0.16$ & 57 (48 to 67$)$ & 96 (95 to 97 ) & $14.59 / 0.44$ \\
\hline Monolayer (optimised interpretation) & 83 (80 to 86$)$ & 85 (81 to 89$)$ & $5.42 / 0.20$ & 61 (52 to 71$)$ & 95 (94 to 96$)$ & $11.54 / 0.41$ \\
\hline \multicolumn{7}{|l|}{ RLU/cut-off value ratio $>1.0 \ddagger$} \\
\hline HPV DNA (high risk types) & 79 (74 to 83$)$ & 77 (71 to 83$)$ & $3.46 / 0.28$ & 64 (53 to 76$)$ & 86 (85 to 88 ) & $4.73 / 0.41$ \\
\hline HPV DNA (high and low risk types) & 82 (77 to 86$)$ & 74 (67 to 80$)$ & $3.13 / 0.25$ & 69 (58 to 79$)$ & 83 (81 to 85$)$ & $4.09 / 0.38$ \\
\hline \multicolumn{7}{|c|}{$\geq$ Low grade squamous intraepithelial lesions or RLU/cut-off value ratio >1.0 if ASCUS/AGUS $\pi$} \\
\hline $\begin{array}{l}\text { Monolayer (clinical reading) or HPV } \\
\text { DNA (high risk types) if } \\
\text { ASCUS/AGUS }\end{array}$ & 87 (83 to 91$)$ & 66 (58 to 73$)$ & $2.41 / 0.20$ & $59(47$ to 70$)$ & 96 (95 to 97$)$ & $13.50 / 0.43$ \\
\hline $\begin{array}{l}\text { Monolayer (optimised interpretation) } \\
\text { or HPV DNA (high risk types) if } \\
\text { ASCUS/AGUS }\end{array}$ & $85(80$ to 89$)$ & 82 (76 to 88$)$ & $4.75 / 0.19$ & 67 (56 to 78$)$ & 94 (92 to 95$)$ & $10.86 / 0.35$ \\
\hline
\end{tabular}

${ }^{*}$ Clinical reading: conventional smear superior to monolayer for both sensitivity $(\mathrm{p}<0.05)$ and specificity $(\mathrm{P}<0.001)$. Optimised interpretation: conventional smear superior to monolayer for specificity $(\mathrm{P}<0.05)$ but not for sensitivity $(\mathrm{P}=0.07)$.

†Clinical reading: conventional smear superior to monolayer for sensitivity $(\mathrm{P}<0.001)$ but not for specificity $(\mathrm{P}=0.07)$. Optimised interpretation: conventional smear superior to monolayer for specificity $(\mathrm{P}<0.001)$ but not for sensitivity $(\mathrm{P}=0.08)$.

†HPV results expressed as relative light units (RLUs), which represent ratio of light emission of sample to average of three positive controls provided by manufacturer, containing $1 \mathrm{pg} / \mathrm{ml} \mathrm{HPV}$ 16 DAN. RLU $\geq 1 \&$ comma; corresponding to $\geq 5000 \mathrm{HPV}$-DNA copies per test well, was considered to be positive.

§Sensitivity and specificity of HPV DNA testing (high risk types) lower $(\mathrm{P}<0.0001)$ than both cytological techniques.

१Clinical reading: paired monolayers/HPV testing superior but not significantly to standard conventional smear for sensitivity $(P=0.88)$ and inferior for specificity $(P<0.001)$. Optimised

interpretation: paired monolayers/HPV testing superior but not significantly to standard conventional smear for sensitivity $(P=0.06)$ and inferior for specificity $(P<0.001)$. 
Table 6 Sensitivity, specificity, and likelihood ratios of conventional cervical smear testing, monolayer, and human papillomavirus (HPV) DNA testing for detection of cervical intraepithelial neoplasia grade II and above

\begin{tabular}{|c|c|c|c|c|c|c|}
\hline \multirow[b]{2}{*}{ Abnormality threshold } & \multicolumn{3}{|c|}{ Colposcopy } & \multicolumn{3}{|c|}{ Screening } \\
\hline & Sensitivity $(95 \% \mathrm{Cl})$ & Specificity $(95 \% \mathrm{CI})$ & $\begin{array}{l}\text { Likelihood ratio+/ } \\
\text { likelihood ratio- }\end{array}$ & Sensitivity $(95 \% \mathrm{Cl})$ & Specificity ( $95 \% \mathrm{CI})$ & $\begin{array}{c}\text { Likelihood ratio+/ } \\
\text { likelihood ratio- }\end{array}$ \\
\hline \multicolumn{7}{|c|}{ ZHigh grade squamous intraepithelial lesions * } \\
\hline Cervical smear (clinical reading) & 83 (78 to 87$)$ & 90 (87 to 92$)$ & $8.17 / 0.19$ & 51 (36 to 67$)$ & 99(99 to 100$)$ & $67.53 / 0.49$ \\
\hline Monolayer (clinical reading) & 79 (74 to 84$)$ & 89 (87 to 92$)$ & $7.34 / 0.24$ & 51 (36 to 67$)$ & 99 (98 to 99$)$ & $43.25 / 0.49$ \\
\hline $\begin{array}{l}\text { Cervical smear (optimised } \\
\text { interpretation) }\end{array}$ & 85 (81 to 89$)$ & 92 (89 to 94$)$ & $10.36 / 0.16$ & 60 (45 to 75$)$ & 99(99 to 99) & $60.46 / 0.40$ \\
\hline Monolayer (optimised interpretation) & 78 (73 to 83$)$ & 94 (92 to 96$)$ & $12.19 / 0.23$ & 65 (50 to 80$)$ & 98 (98 to 99$)$ & $41.29 / 0.36$ \\
\hline \multicolumn{7}{|l|}{ RLU/cut-off value ratio $>1.0 \dagger$} \\
\hline HPV DNA (high risk types) & 80 (74 to 86$)$ & $54(49$ to 60$)$ & $1.75 / 0.37$ & $96(88$ to 100$)$ & 85 (83 to 87$)$ & $6.52 / 0.05$ \\
\hline HPV DNA (high and low risk types) & 81 (75 to 87$)$ & $50(44$ to 55$)$ & $1.60 / 0.39$ & 96 (88 to 100$)$ & 82 (80 to 84$)$ & $5.32 / 0.05$ \\
\hline \multicolumn{7}{|c|}{ ZHigh grade squamous intraepithelial lesions or RLU/cut-off value ratio >1.0 if ASCUS/AGUS $¥$} \\
\hline $\begin{array}{l}\text { Monolayer (clinical reading) or HPV } \\
\text { DNA (high risk types) if } \\
\text { ASCUS/AGUS }\end{array}$ & 82 (76 to 88 ) & 86 (82 to 90$)$ & $5.94 / 0.21$ & 64 (45 to 83$)$ & 98 (97 to 99$)$ & $28.47 / 0.37$ \\
\hline $\begin{array}{l}\text { ‡Monolayer (optimised } \\
\text { interpretation) or HPV DNA (high } \\
\text { risk types) if ASCUS/AGUS }\end{array}$ & 80 (74 to 86$)$ & 93 (90 to 96$)$ & $11.60 / 0.21$ & 76 (59 to 93 ) & 97(97 to 98$)$ & $29.71 / 0.25$ \\
\hline
\end{tabular}

${ }^{*}$ Clinical reading: conventional smear is superior to monolayer but not significantly for both sensitivity $(P=0.12)$ and specificity $(P=0.16)$. Optimised interpretation: conventional smear is superior to monolayer for sensitivity $(\mathrm{P}<0.001)$ but not for specificity $(\mathrm{P}=1.00)$

tSensitivity of HPV DNA testing (high risk types) is higher but not significantly than that of conventional smear $(\mathrm{P}=0.66)$ but specificity is lower ( $\mathrm{P}<0.0001)$.

$\neq C$ linical reading: paired monolayers/HPV testing is superior but not significantly to standard conventional smear for sensitivity $(P=0.29)$ but inferior for specificity $(P<0.001)$. Optimised interpretation: paired monolayers/HPV testing is superior but not significantly to standard conventional smear for sensitivity $(P=0.73)$ but inferior for specificity $(P<0.001)$.

\section{What is already known on this topic}

New technologies have been developed to improve the detection of cervical cancer and its precursors and reduce the rate of false negative results from conventional cervical smear tests

In several countries liquid based monolayer cytology is replacing conventional smear tests, despite controversy about whether these more expensive tests perform better

\section{What this study adds}

Conventional cervical smear testing is superior in terms of low and high grade lesions and in populations with a low or a high incidence of abnormalities

Monolayer testing is less reliable and should not replace conventional cervical smear testing

8 The Bethesda system for reporting cervical/vaginal cytologic diagnoses: revised after the second National Cancer Institute Workshop, April, 29-30, 1991. Acta Cytol 1993;37:115-24.

9 Poljak M, Brencic A, Seme K, Vince A, Marin IJ. Comparative evaluation of first- and second-generation digene hybrid capture assays for detection of human papillomaviruses associated with high or intermediate risk for cervical cancer. J Clin Microbiol 1999;37:796-7.

10 Fleiss J. Statistical methods for rates and proportions. New York: Wiley, 1981

11 Hutchinson ML, Zahniser DJ, Sherman ME, Herrero R, Alfaro M, Bratti $\mathrm{MC}$, et al. Utility of liquid-based cytology for cervical carcinoma screening: results of a population-based study conducted in a region of Costa Rica with a high incidence of cervical carcinoma. Cancer 1999;87:48-55

12 Sheets EE, Constantine NM, Dimisco S, Dean B, Cibas ES Colposcopically directed biopsy provide a basis for comparing the accuracy of ThinPrep and Papanicolaou smears. J Gynecol Tech 1995;1:27-33.

13 Bishop JW, Bigner SH, Colgan TJ, Husain M, Howell LP, McIntosh KM, et al. Multicenter masked evaluation of AutoCyte PREP thin layers with matched conventional smears. Including initial biopsy results. Acta Cytol 1998;42:189-97.

14 Roberts JM, Gurley AM, Thurloe JK, Bowditch R, Laverty CRA. Evaluation of the Thin Prep pap test as an adjunct to the conventional Pap smear. Med J Aust 1997;167:466-9.

15 Bolick DR, Hellman DJ. Laboratory implementation and efficacy assessment of the ThinPrep cervical cancer screening system. Acta Cytol 1998;42:209-13.
Table 7 Interobserver reliability for conventional smear tests and monolayer tests*

\section{Second interpretation}

\begin{tabular}{lccccc} 
& \multicolumn{7}{c}{ Second interpretation } \\
\cline { 2 - 7 } First interpretation & Normal & ASCUS/AGUS & LSIL & HSIL & Invasive cancer \\
\hline Cervical smear & & & & & \\
\hline Normal & 448 & 35 & 15 & 13 & 0 \\
\hline ASCUS/AGUS & 13 & 25 & 14 & 4 & 0 \\
\hline LSIL & 34 & 11 & 33 & 8 & 0 \\
\hline HSIL & 6 & 4 & 4 & 86 & 0 \\
\hline Invasive cancer & 0 & 0 & 0 & 0 & 8 \\
\hline Monolayer cytology & & & & & 0 \\
\hline Normal & 442 & 33 & 14 & 8 & 0 \\
\hline ASCUS/AGUS & 29 & 11 & 10 & 6 & 0 \\
\hline LSIL & 48 & 10 & 28 & 10 & 0 \\
\hline HSIL & 16 & 10 & 22 & 65 & 0 \\
\hline Invasive cancer & 0 & 0 & 0 & 0 & 2 \\
\hline
\end{tabular}

* Data available (two blinded interpretations) for 761 conventional smear slides and 764 monolayer slides.

16 Park IA, Lee SN, Chae SW, Park KH, Kim JW, Lee HP. Comparing the accuracy of ThinPrep Pap tests and conventional Papanicolaou smears on the basis of the histologic diagnosis: a clinical study of women with cervical abnormalities. Acta Cytol 2001;45:525-31.

17 Manos MM, Kinney WK, Hurley LB, Sherman ME, Shieh-Ngai J, Kurman $\mathrm{RJ}$, et al. Identifying women with cervical neoplasia: using human papillomavirus DNA testing for equivocal Papanicolaou results. JAMA 1999:281:1605-10

18 Ronnett BM, Manos MM, Ransley JE, Fetterman BJ, Kinney WK, Hurley $\mathrm{LB}$, et al. Atypical glandular cells of undetermined significance (AGUS): cytopathologic features, histopathologic results, and human papillomavirus DNA detection. Hum Pathol 1999;30:816-25.

19 Bergeron C, Jeannel D, Poveda J, Cassonnet P, Orth G. Human papillomavirus testing in women with mild cytologic atypia. Obstet Gynecol 2000;95:821-7.

20 Schneider A, Hoyer H, Lotz B, Leistritza S, Kuhne-Heid R, Nindl I, et al. Screening for high-grade cervical intra-epithelial neoplasia and cancer by testing for high-risk HPV, routine cytology or colposcopy. Int J Cancer 2000;89:529-34.

21 Ferenczy A, Robitaille J, Franco E, Arseneau J, Richart RM, Wright TC. Conventional cervical cytologic smears vs. Thin Prep smears. A paired comparaison study of cervical cytology. Acta Cytol 1996;40:1136-42

22 Bergeron C, Bishop J, Lemarie A, Cas F, Ayivi J, Huynh B, et al. Accuracy of thin-layer cytology in patients undergoing cervical cone biopsy. Acta Cytol 2001;45:519-24.

23 Bernstein SJ, Sanchez-Ramos L, Ndubisi B. Liquid-based cervical cytologic smear study and conventional Papanicolaou smears: a metaanalysis of prospective studies comparing cytologic diagnosis and sample adequacy. Am J Obstet Gynecol 2001;185:308-17.

24 Kaufman RH. Is there a role for human papillomavirus testing in clinical practice? Obstet Gynecol 2001;98:724-5.

(Accepted 29 January 2003) 